\title{
Emerging Market Multinational Family Business Groups and the Use of Family Managers in Foreign Subsidiaries
}

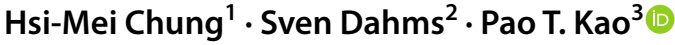

Received: 8 May 2019 / Revised: 14 December 2020 / Accepted: 4 January 2021 /

Published online: 3 March 2021

(C) The Author(s) 2021

\begin{abstract}
Little is known about the internationalization behavior of Emerging Market Family Business Groups (EFBGs) and their strategic usage of family managers in foreign subsidiaries facing uncertainty due to institutional differences. Informed by the resource-based view of the firm and by institutional theory, we hypothesize that family managers are an EFBGs-specific resource used to mitigate institutional uncertainty caused by larger institutional distances occurring between home and host countries. Moreover, family managers are used differently depending on the regional focus of the EFBGs, which further strengthens the critical role that family manager's play in management and control across the business groups. We employ 5-year panel data on Taiwanese EFBGs, and our results indicate that family managers tend to be assigned by EFBGs with stronger operations outside the home region, and in foreign subsidiaries where strong differences in regulative and cognitive institution may exist. We contribute to the continuing understanding of family ownership in the management of EFBGs, and the research of internationalization of firms on managing foreign subsidiaries.
\end{abstract}

Pao T. Kao

Pao.Kao@fek.uu.se

Hsi-Mei Chung

smchung@isu.edu.tw

Sven Dahms

svendahms@hotmail.com

1 Department of Business Administration, I-Shou University, No. 1, Sec. 1, Syuecheng Rd., Dashu District, Kaohsiung City 84001, Taiwan

2 The Open University of Hong Kong, 30 Good Shepherd St, Ho Man Tin, Hong Kong, SAR, China

3 Department of Business Studies, Uppsala University, Kyrkogårdsgatan 10, 75120 Uppsala, Sweden 
Keywords Emerging market family business groups · Family managers · Family business ownership · Institutional distance $\cdot$ Regional orientation · Internationalization · Taiwan

\section{Introduction}

We examine how Emerging Market Family Business Groups (EFBGs) utilize family managers during the process of internationalization. EFBGs are defined as a set of legally independent affiliations found in emerging markets that are tightly interconnected with each other through various forms of family ownership. While family ownership tends to be overlooked in the U.S. and U.K., it is quite common in other parts of the world, including many emerging economies (Edwards et al. 2019; Hernandez and Guillén 2018; Khanna and Rivkin 2001, 2006; La Porta et al. 1999; Mukherjee et al. 2019; Piana et al. 2018; Pihkala et al. 2019; Rosa et al. 2019). EFBGs tend to put a stronger emphasis on the promotion of family values and family wealth maximization across their international network of subsidiaries (Arregle et al. 2007; Carney and Gedajlovic 2002; Gómez-Mejía et al. 2007; Peng and Jiang 2010; Steier 2009; Young et al. 2008). This often requires EFBGs to concentrate decision-making activities and management among family members (Carney 1998; Daspit et al. 2018; Deephouse and Jaskiewicz 2013; Pihkala et al. 2019). Therefore, family managers enjoy direct access to decision making through their regular involvement in management (Sirmon and Hitt 2003). In emerging economies where market-supporting institutions, for instance, capital markets, tend to be incomplete and ever-changing (North 1990; Peng 2003), using family members to manage diversification can be particularly valuable for EFBGs to deal with uncertainty (Khanna and Rivkin 2001; Khanna and Yafeh 2007). There is strong trust-bond between members of the family (Zellweger et al. 2019). This type of particularistic relationship is characterized by mutual obligation (Luo and Chung 2005), which can facilitate rapid information and knowledge exchanges to achieve immediate decision-making progress (Peng et al. 2017; Zellweger et al. 2019). As EFBGs move forward in internationalization and establish subsidiaries that are internationally dispersed (Guillén 2000), family managers can play an even stronger role and function as a critical resource in the coordination and management of businesses.

Although family managers as a resource can be valuable, with characteristics difficult to imitate, and relatively easy to be organized, they are unfortunately also extremely limited in both scale and scope since there are only a few family members available to be involved across the EFBGs. For example, Evergreen Group is a large Taiwanese family business group that consists of 18 affiliated businesses that span marine shipping and logistics, airlines, and hotel industries. Evergreen Marine Corp. alone has approximately 40 direct and indirect invested companies around the world (Evergreen Marine Corp 2019). It is difficult to imagine that EFBGs can fill all of their senior managerial positions with immediate family members alone. 
Therefore, it is a strategic challenge for EFBGs to manage where to assign family members internationally. Conversely, most studies related to family management and family member involvement have focused on the corporate level but have ignored the pivotal role it plays during internationalization (Bannò and Sgobbi 2016; Tabor et al. 2018). Our research objective is to address this gap by examining the practical utilization of family managers established in foreign subsidiaries. More specifically, we ask the research question, "What is the relationship between institutional distance and the likelihood that the heads of foreign subsidiaries are family managers?" We ground our framework of EFBGs at the intersection between a resource-based view (RBV) of the firm (Habbershon and Williams 1999; Sirmon and Hitt 2003) and institutional theory (Khanna and Palepu 2000; Khanna and Rivkin 2001, 2006; Kostova 1999; Kostova and Zaheer 1999; Scott 1995). Family managers and their family ties are conceptualized as resources specific to EFBGs (Barney 1986, 1991; Luo 2000; Tan and Mahoney 2003; Trevino and Grosse 2002), which can be utilized by EFBGs in foreign subsidiaries to enhance control and coordination and to reduce the uncertainty caused by differences in regulative, normative and cognitive distances between home and host countries (Leitch et al. 2013; Platje 2008; Zellweger et al. 2019). Moreover, based on insights provided by previous regionalization research (Edwards et al. 2019; Verbeke and Kano 2016), we expect that the use of family managers in foreign subsidiaries is not always a straightforward procedure; and, it can change when EFBGs cross regional borders and become more international (Vandekerkhof et al. 2015). This can be particularly intriguing as institutional theory, in general, assumes the dominance of external institutional forces (Peng 2003; Scott 1995), and it does not take into consideration how organizational variation may influence the degree of conformity among such subsidiaries (Fortwengel 2017). As such, we further investigate and compare whether the tendency of using family managers in subsidiaries is consistent among those EFBGs that focus their activities within or outside of the home region. Because of evident variations in and among EFBGs' regional orientations, we expect that the need to use family managers may also differ to some extent.

Utilizing family managers to deal with the uncertainty experienced during the process of internationalization raises important theoretical considerations that cannot be easily accommodated by existing frameworks in family business and international business literature. For example, agency theory has been used extensively in the field of family business to identify governance issues such as principal-principal conflicts in EFBGs (Sauerwald and Peng 2013). But, the theoretical notion of internal focus makes it inadequate in explaining staffing decisions under conditions of cross-country, institutional differences and the uncertainties experienced (Vandekerkhof et al. 2015). Furthermore, a recent focus has been placed upon a family member being thought of as the holder of a relational contract (Peng and Jiang 2010), one who plays a role to maximize the socio-emotional wealth of the family business (Gómez-Mejía et al. 2007, 2011). The internationalization patterns of family businesses, according to this view, will be more cautious in nature as compared to their non-family peers due to their need for control and an intrinsic risk-averse attitude (Berrone et al. 2012; Del Bosco and Bettinelli 2020; Hennart et al. 2017). 
Yet, the empirical results are rather inconclusive (Arregle et al. 2017; Hernández et al. 2018; Hsueh and Gomez-Solorzano 2019), and this has led to a call for greater contextual understanding (Hennart et al. 2017; Peng et al. 2018). The international business literature, on the other hand, focusses on how the transferability of firmspecific advantages from the headquarters to foreign subsidiaries will be affected by the institutional differences occurring between home and host countries (Rugman et al. 2011; Verbeke and Kano 2016). Despite its emphasis and discussion relevant to external contingencies, scholars often brush aside the potential variations on strategic decision-making due to firm heterogeneity (Rugman and Verbeke 2008). Our current study aims to join the theoretical discussions stated above, and to a further extent, consider family relational-advantage arguments more closely (Chrisman et al. 2009).

More specifically, our study on EFBGs and their use of family managers in foreign subsidiaries makes the following contributions. Firstly, we extend the discussion of family ownership and how family control is maintained in the management of the foreign subsidiaries when expanding internationally (Gómez-Mejía et al. 2007, 2011). We focus our discussions on the role of family managers in foreign subsidiaries and draw on RBV and institutional theory to argue that these family managers are valuable resources specific to EFBGs when used to mitigate the uncertainty perceived from operating in countries with larger institutional differences. We empirically test how institutional contingencies affect family-manager, subsidiary-staffing decisions, and our findings show the need to maintain family control is indeed prevalent. Additionally, our findings further show the heterogeneity of EFBGs along the regional dimension, and how this phenomenon will impact their strategic management. For EFBGs that place a stronger emphasis on markets in their home region, the family managers are strategically needed at the headquarters; as a result, the institutional uncertainty of foreign subsidiary operations is inevitably overlooked. This last result provides evidence of the deviating behavior of standard practices under the host institution's aegis (Fortwengel 2017), and it further supports our argument that family managers are an important EFBG-specific resource.

Secondly, we also contribute to the research on internationalization processes in showing how EFBGs are key to the development of coordination and control of cross-border business activities (Vahlne and Johanson 2017). Previous literature on international expatriate and staffing decision-making has either ignored EFBGs (Ando and Paik 2013; Gaur et al. 2007), or overlooked the increasing importance of subsidiaries (Rugman et al. 2011). Furthermore, family managers are a unique expatriate staffing resource that is uniquely available to family-owned business groups, with this crucial omission hindering our understanding of the field (Zellweger 2017). Moreover, the use of family managers is not the same for EFBGs placing stronger emphasis on markets located in their home or non-home regions. This last point indicates a real insight into the differences between family managers and professional managers.

The remainder of this article is structured as follows. In the next section, existing studies on the impact of host-country institutions related to a business group's behavior during internationalization are reviewed and hypotheses are developed. We then explain our method, data source, variables, and statistical analysis. Section 4 
presents the results of our analysis and hypotheses testing, while a discussion of these is made in the section following. Lastly, we conclude this paper with a brief summary of findings, limitations and potential for future research.

\section{Theory and Hypotheses Development}

\subsection{Family Managers as a Specific Resource Utilized During EFBGs Internationalization}

EFBGs internationalization refers to the processes utilized to expand business operations internationally (Johanson and Vahlne 1977, 2009; Vahlne and Johanson 2017). Within the context of EFBGs, internationalization is concerned with how business activity is managed and then coordinated across a network of internationally-dispersed subsidiaries (Ghoshal and Bartlett 1990). While EFBGs would like to actively pursue family ownership opportunities and promote familyvalues throughout the business groups by using family managers in every strategic position, there is simply an insufficient number of family members to accomplish this purpose.

The strategic dilemma of using family managers during the internationalization of EFBGs has been often overlooked in previous studies (Jaskiewicz et al. 2017; Zellweger et al. 2019). While previous studies have investigated the use of family managers vis-à-vis the boundary of family business groups (Khanna and Rivkin 2006; Yiu et al. 2007), the growth and development of family businesses (Carney 1998; Gedajlovic and Carney 2010), corporate governance of family enterprises (Carney and Gedajlovic 2002; Gómez-Mejía et al. 2001; Peng and Jiang 2010; Piana et al. 2018), internationalization decision performance (Purkayastha et al. 2017; Hernández et al. 2018) organizational social capital (Arregle et al. 2007), and institutional capabilities (Carney et al. 2016), there has been relatively little understanding of how family managers are able to contribute to EFBGs' international expansion, and to an even lesser extent how they are utilized to coordinate and control foreign subsidiaries that are internationally dispersed.

Family managers share the common interest along with EFBGs to preserve family values and promote family wealth (Arregle et al. 2007; Gómez-Mejía et al. 2007; Peng and Jiang 2010; Steier 2009; Young et al. 2008). They also display greater influence in EFBGs and will expect to be heard during decision-making (Yiu et al. 2007). This is due in large part to family managers connections with other family members by way of family ties characterized by mutual trust and reciprocal obligations (Chung and Luo 2008; Miller et al. 2017; Peng and Jiang 2010). Family ties indicate a shared personal, ethnic and communal background that will allow family managers to interact with one another on the basis of commonly-held beliefs and attitudes (Leff 1978). Family ties also enable coordination that is "either insufficient or unavailable in formal institutions" (Bian 1997, p. 369). Transactions made through family ties are a mixture of arm-length and relational contracting (Carney 2005), which facilitates a faster exchange of tacit knowledge, as well as sensitive information across the EFBGs (Miller and Le 
Breton-Miller 2006; Peng et al. 2017). Due to the existence of family ties, family managers are often believed to have more freedom to use heuristic methods and to become more entrepreneurial in capturing important business opportunities (Carney 2005; Carney et al. 2016, 2018; Kotlar and Sieger 2019).

Especially, EFBGs in emerging markets are known to utilize family managers within the groups to bypass incomplete market support systems (North 1990; Khanna and Palepu 2000; Khanna and Rivkin 2001, 2006; Peng 2003). Family managers in EFBGs provide a less formalized, yet more agile, mechanism to coordinate and control business efficiently (Luo and Chung 2005, 2013), and to form an internal institution that mitigates information asymmetries in those emerging markets (Daspit et al. 2018; Tabor et al. 2018). EFBGs utilize family managers to reduce the cost of transactions (Edwards et al. 2019; Verbeke and Kano 2012), and reduce the level of uncertainty in the business environment (Khanna and Rivkin 2001, 2006). Therefore, the knowledge and capability of using family managers in EFBGs to generate economic returns is a valuable and critical EFBGs-specific resource (Barney 1986, 1991; Eddleston et al. 2007; Guillén 2000; Habbershon and Williams 1999; Tan and Mahoney 2003). This specific resource is also rare as it cannot be applied to non-family managers, or for non-EFBGs to imitate, and it is embedded within the specific EFBGs themselves (Trevino and Grosse 2002; Young et al. 2014). A resource-based view (RBV) of EFBGs also implies a managerially-oriented perspective (Barney 1991; Penrose 1959), which particularly argues for a unique capability to be developed under the restrictive market-supporting system seen in emerging markets (Guillén 2000; Luo 2000; Sirmon and Hitt 2003). Nevertheless, the usage of family managers has its limitations. Family managers may not possess the requisite experience and prior knowledge needed for EFBGs internationalization which could hence delay and restrict their progress (Bannò and Sgobbi 2016; Del Bosco and Bettinelli 2020; Vandekerkhof et al. 2015). As stated previously, there are only a finite number of direct family members available useful across the FBGs. Although family ties may be extended through inter-family marriages, as well as practical with people from a similar ethnic background (Granovetter 1995), there is still a limit to the number of individuals possessing family ties that an EFBG could assign as managers (Daspit et al. 2018).

As EFBGs internationalize, it can be expected that family managers will play an ever more important role in managing their foreign expansion. As a specific resource available to EFBGs, the use of family managers needs to be matched closely to the host country's institutional environment (Trevino and Grosse 2002; Young et al. 2014). EFBGs ought to carefully decide where family managers should be assigned to, as there may be positions inside the business groups that are more crucial than others.

\subsection{Family Managers' Location and Institutional Distance in Foreign Subsidiaries}

Institutions refer to higher social orders or patterns of the polity and political economy (Jepperson 1991). Institutions govern how information is perceived and processed and what kinds of actions are socially acceptable (DiMaggio and Powell 
1983; Meyer and Rowan 1977). The three distinctive pillars of the institutional environment (i.e., regulative, normative, and cognitive) enforce how individuals and organizations are conformed through implementation of coercive, normative, and mimetic processes (Scott 1995). Institutional theory highlights the challenges foreign subsidiaries of EFMGs face as their operations become embedded in home and host country's institutional environments. On the one hand, foreign subsidiaries ought to conform to external institutional settings in the host countries in order to obtain legitimacy allowing both survival and success (Ahworegba 2018; Peng 2003; Peng and Heath 1996). On the other hand, they also need to follow the managerial practice and organizational routines that were set up to protect family values and to promote family wealth leading to achieved internal legitimacy (Phillips and Tracey 2009; Phillips et al. 2009).

Institutional distance captures the similarity and dissimilarity apparent between the institutional settings of two countries (Eden and Miller 2004; Fortwengel 2017; Kostova and Zaheer 1999; Xu and Shenkar 2002). It recognizes different forms of institutional environments and reflects the uncertainty EFBGs experience whenever expanding internationally (Beugelsdijk et al. 2018; Fortwengel 2017; Phillips et al. 2009). Institutional distance has been used to explain a firm's ownership strategy in foreign subsidiaries (Gaur and Lu 2007), the transfer of organizational practices (Kostova 1999; Kostova and Roth 2002), and subsidiary staffing decisions (Gaur et al. 2007). Institutional distance reflects the EFBGs' dilemma in adopting local responsiveness vs. global integration strategies (Prahalad and Doz 1987; Xu and Shenkar 2002). Large institutional distance suggests a greater dissimilarity in the institutional environments of the host- and home-countries, and it presents greater challenges for EFBGs to transfer and implement managerial routines and practices first developed in their home-countries (Kostova 1999; Kostova and Roth 2002; Zaheer 1995). It also indicates that foreign subsidiaries of EFBGs face stronger pressure to deal with such differences in the external and internal institutional settings (Ambos and Ambos 2009; Xu et al. 2004), which can lead them to a merely ceremonial adoption of managerial practices (Kostova and Roth 2002; Miller et al. 2017), and subsequently a threat to their survival.

In line with Scott (1995), we distinguish the regulative, cognitive, and normative dimensions of institutional differences (Estrin et al. 2007; Gaur et al. 2007). We focus on the uncertainty stemming from the institutional distance between homeand host-countries, and argue that EFBGs utilize family managers to manage the uncertainty of coordination and control while operating in foreign markets. As such, institutional distance does not merely imply differences in economic development (Beugelsdijk et al. 2018). Rather, it describes the uncertainty inherent during the process of internationalization (Johanson and Vahlne 1977, 2009).

The regulative institutional distance indicates dissimilarity of the legal system of the host and home countries (Scott 1995). Larger distance in regulative institutions presents challenges as the rules and policies of the EFBGs that are designed and suitable for the home markets may not be entirely applicable for the foreign subsidiaries in the host markets (Eden and Miller 2004; Kostova 1999; $\mathrm{Xu}$ and Shenkar 2002). Therefore, EFBGs' incentives aimed to promote family loyalty may be difficult to implement in the foreign subsidiaries. As such, foreign 
subsidiaries can also experience conflict and even develop resistance should EFBGs insist on trying to install certain regulatory measures. The utilization of family managers in foreign subsidiaries with larger regulative, institutional distance can potentially manage this uncertainty. They can reduce conflicts by solving it swiftly, as they have direct access to other family members in the EFBGs for faster decision-making, and strength and freedom in execution. As such, negative implications from legal disputes in the host-country may be eased. Moreover, the presence of these family managers may provide a direct and personal influence that can deliver family loyalty in an informal manner. With a family manager at the head of a foreign subsidiary, he or she can practicably establish a personal relationship with individuals in that subsidiary, which may serve to promote family values through a less confrontational way. Hence, our first hypothesis is as follows:

Hypothesis 1a: EFBGs are more likely to use family managers in foreign subsidiaries when the regulative institutional distance between host- and home-countries is greater.

Cognitive institutions shape the belief systems and cultural frames that generate meaning for individuals and organizations in society (Scott 1995). They may include national culture, social structure and cohesion, and how society sees power and uncertainty (Hofstede 1980). Larger cognitive institutional distance indicates a greater difference whenever EFBGs and foreign subsidiaries need to interpret cultural symbols and practices (Eden and Miller 2004; Kostova 1999; $\mathrm{Xu}$ and Shenkar 2002). For example, the perception of family and how family members should act toward one another can be quite distinctive from the home country of the EFBGs to the countries hosting their subsidiaries. Greater distancing in the cognitive-institutional dimension can prevent subsidiaries from understanding the culture of the EFBGs properly, which in turn may cause a threat towards maintaining family values. To address the uncertainty due to larger cognitive-institutional distance, family managers in foreign subsidiaries may wish to better understand the belief system and cultural frames of the host markets in person, and to identify an appropriate way to adopt and adapt the family values of the EFBGs. The personal relationship that family managers establish through more than a passing acquaintance with host nationals not only helps them to achieve acceptance by foreign subsidiaries staff, but it also enables them to become familiar with the local society and culture to introduce the family culture of EBFGs in a more acceptable way. Hence, our next hypothesis is as follows:

Hypothesis 1b: EFBGs are more likely to use family managers in foreign subsidiaries whenever the cognitive institutional distance between host and home countries is greater

Normative institutions refer to the norms and values in the society that prescribe desired goals and obligations for individuals and organizations (Scott 1995). Examples of normative institutions that the EFBGs may encounter when entering foreign countries may include different views on family values, what 
is considered to be ethical, or engagement and responsibility to society and community when among others. While these norms and values may be shown in activities, what is considered as appropriate may not become observable or even understandable. Therefore, normative institutional distance can create great uncertainty for the EFBGs as the family value, which is core to the business, and how it is practiced may be interpreted differently in the home- and host-countries (Eden and Miller 2004; Kostova 1999; Xu and Shenkar 2002). Family managers assigned in foreign subsidiaries have the ability to swiftly address any conflicts raised by normative-institutional distance. For instance, what is considered to be socially responsible in a host country along with what can be implemented may need the go-ahead by family managers (Jackson and Apostolakou 2010). Therefore, the utilization of family managers in foreign subsidiaries with large normative-institutional distance can prevent negative repercussions due to not knowing the appropriate norms and values of the host countries properly. Since family managers also represent the family, a signal of commitment is being sent to the local actors that will develop greater legitimacy (Yiu and Makino 2002), and reduce the external cost of the transaction (Young et al. 2008).

Hypothesis 1c: EFBGs are more likely to use family managers in foreign subsidiaries when the normative institutional distance between host and home countries is greater.

\subsection{The use of family managers in home-region vs. non-home, region-oriented EFBGs}

While institutional theory in general assumes the dominance of institutional settings and the pressure for organizations to conform, some scholars have argued that deviating behavior may still occur (Fortwengel 2017). There is also a growing awareness in the literature that family business groups are heterogenous rather than homogenous in the conduct of their internationalization strategies (Daspit et al. 2018). Due to the emphasis on preserving family value and strong connections with the home country, EFBGs might tend to be regionally-oriented, and their conduct and operations (e.g., internal policy, corporate culture, and norms and values) become rather regionalized (Schaaper et al. 2013). As such, when EFBGs internationalize and increasingly expand outside their home region, they may face more uncertainty that will require both strategic management and control (Verbeke and Kano 2016).

In other words, the tendency of using family managers in foreign subsidiaries may be a more pressing issue for some EFBGs than not. As the number of qualified family managers is limited, EFBGs with stronger operations outside the home region may have a greater tendency to utilize family managers in foreign markets with larger institutional distance when compared to their counterparts (Wan and Hoskisson 2003). Home region refers to the triadic regions where the EFBGs are located. Triadic regions are the agglomeration of attractive and approximate foreign markets in geographic space (Rugman and Verbeke 2004), for instance, the European Union (E.U.), North America Free Trade Agreement (NAFTA), etc. A homeregion oriented, Asian EFBG, for example, is one with most of its revenue coming 
from the Asian region. The geographical distribution of sales can "shape and constrain most important decisions and actions" (Rugman and Verbeke 2004: p. 7), and it implies where the concentration of the downstream marketing-related assets of EFBGs are located.

The ability of EFBGs to connect their assets developed back at home with those that are part of foreign subsidiaries will also determine how successful they are internationally (Rugman and Verbeke 2005). EFBGs that focus strongly on the home region will have a network of foreign subsidiaries that are predominantly located close to the home country. While marketing assets and other resources may be concentrated in the headquarters' region, it is relatively easy to mobilize these capabilities to manage foreign subsidiaries due to the closer geographic distance. This will not be the case for EFBGs which focus outside their home region, as their foreign subsidiaries tend to be distant and unable to receive immediate assistance from the headquarters. EFBGs that do not focus on the home region may have a stronger tendency to utilize family managers and assign them in the foreign subsidiaries to maintain control and reduce the cost of transactions (Edwards et al. 2019; Verbeke and Kano 2012). As such, we can propose the following hypothesis:

Hypothesis 2: EFBGs focus outside the home region are more likely to use family managers in foreign subsidiaries with a larger institutional distance than those with a home-region focus.

\section{Research Method and Data}

\subsection{Data Source and Sample Description}

We chose EFBGs from Taiwan to test our framework. Despite having a relatively small population of less than 25 million, Taiwan is one of the world's 23 largest economies (CIA 2018). Taiwanese EFBGs have largely evolved from the institutional incentives provided in Taiwan (Chung 2001), and they have played a dominant role in the country's industrialization and economic development past (Chang 2006; Chung and Luo 2008). As a newly industrialized economy, internationalization is the norm for most Taiwanese EFBGs due to the limited size of the domestic market. Especially, Taiwanese EFBGs are also known for the use of family managers in international management situations to control overseas companies and subsidiaries through an intertwined-ownership network (Chung 2014; Chung and Luo 2008). As such, these characteristics make Taiwanese EFBGs a suitable candidate for our research.

Taiwanese EFBGs, also known as "Jituanqiye" (family corporations) (Chung 2001), are conglomerates controlled by one major family unit and consisting of businesses vertically and (or) horizontally integrated. For example, one of the largest EFBGs in Taiwan is controlled by the Hsu family, and it is known collectively as the Far Eastern Group. This EFBG spans across ten industries including petrochemicals, polyester and synthetic fibers, cement, transportation, retail 
and department stores, financial services, etc.; and, it has total assets exceeding NT\$2.46 trillion (US\$82 billion) (Far Eastern Group 2019). Taiwanese EFBGs have played a dominant role in the country's industrialization and economic development (Chang 2006; Chung and Luo 2008; Young et al. 2008). In this respect, Taiwan is representative of many newly industrialized economies, and the results found here can have broader applicability to other rapid-growth economies in Asia.

We obtained data from the China Credit Information Service (CCIS) that includes information on Taiwan's Top 100 business groups. Data from this source has been employed in other research regarding Taiwanese business groups, and it is generally seen as reliable (Chung 2014; Luo and Chung 2005). The Top100 business groups account for more than $70 \%$ of the island's gross national product (GNP) and play a critical role in Taiwan's economy. We selected data from 1999 to 2003 (published between 2001 and 2005) as this 5-year period does not contain any significant economic shifts that may deter outward investment. Another valid reason for selecting this 5-year period is that Taiwanese EFBGs have expanded into overseas markets in a growing trend from the nineties onward (Chang 2006; Lasserre and Schütte 2006). This trend indicates there is a strong need for sophisticated foreign subsidiary management including the decision for a subsidiary-head assignment. Furthermore, family businesses are, in general, relatively stable in terms of both the number of people in management, family roles, and family relationships (Jaskiewicz et al. 2017; Zellweger et al. 2019). With this consideration in mind, EFBGs' interest of using family members in key positions throughout the group is argued to be a relatively stable characteristic. Therefore, our research question can be appropriately answered based on panel data from 1999-2003. Additionally, pooling 5-year's data enabled us to avoid the limitations of biased inference and overcome the implicit assumption that the model parameters are stable (Certo and Semadeni 2006).

CCIS database discloses the Top-100 business groups in Taiwan year-by-year, and it provides information about their foreign expansion. CCIS identifies a business group as an EFBG if (1) it is controlled and managed by a specific family entity, or (2) if it is controlled and managed by a set of families and a previous generation of the same family (or families) has also owned the business. This is consistent with the definition of a family-owned business group provided by scholars and previous studies of family business groups (La Porta et al. 1999; Miller and Le Breton-Miller 2006; Morck et al. 2005; Steier 2009).

During this 5-year period, some EFBGs dropped out of or moved into the Top 100 business groups list. We decided to select EFBGs that were in the list of the Top 100 for at least 3 years during this period to ensure consistency. As a result, a sampling of 49 Taiwanese EFBGs was constructed, and the description of their industry, average age, average assets, average number of affiliations and average number of foreign affiliations can be found in Table 1.

Apart from the CCIS database, secondary sources, e.g., annual reports, company websites, and news releases were used to identify the subsidiaries of these 49 EFBGs and their locations. In total, we identified 5051 subsidiaries located in 43 countries. However, subsidiaries in six countries (Costa Rica, Jordan, Panama, 
Table 1 Description of sample emerging market family business groups

\begin{tabular}{lcc}
\hline Group industry & $\begin{array}{c}\text { Number of } \\
\text { affiliations }\end{array}$ \\
\hline Manufacturing & & 30 \\
Service & & 18 \\
Others & & 1 \\
Total & Average & 49 \\
\hline Affiliation characteristic & 36.78 & Units \\
\hline Affiliation age & 7771.18 & Years \\
Affiliation assets & 52.52 & U.S. million \\
Number of affiliation & 20.06 & Number \\
Number of foreign subsidiaries & & Number \\
\hline
\end{tabular}

Samoa, United Arab Emirates, and Vietnam) were later eliminated due to the lack of data for the institutional scores at the country level. As a result, we ended up with a final sample of 4780 subsidiaries in 37 countries during the 5 years.

\subsection{Measures}

\subsubsection{Dependent Variable}

Family Manager is measured by the difference in the relative status of the foreign subsidiary's head. The foreign subsidiary head is defined as the CEO (Gaur et al. 2007). Because the CCIS database discloses the CEO's name in each foreign subsidiary, we can identify the last name of the CEO and know whether the manager is a family member through the CCIS database (China Credit Information Service 2001, 2002, 2003, 2004, 2005) and cross-check with other secondary sources (e.g., annual reports, magazine reports, Google search etc.). In family-business groups in Taiwan, family members can also be identified by means of a family tree based on blood ties or through marriage (Chung 2001). Our definition of a family member is therefore based on whether the individual in question has a kinship relationship (or relationship through marriage) with the founding family members in the group.

Our coding then compares the status of the subsidiary head between a pair of subsidiaries. If both subsidiaries heads are family members, we code 1 , otherwise, we code 0 . This calculation is consistent with our conceptualization that family managers are a rare resource because there are only a limited number of family members that can be called upon. If one family manager is sent to a particular foreign subsidiary, he or she will not be available for another subsidiary. This method of coding the dependent variable has also been utilized in previous studies (Manev 2003; Manev and Stevenson 2001). 


\subsubsection{Independent Variables}

Regulative, cognitive, and normative institutional distances, which are measured by the absolute difference of the scores between host and home countries in terms of regulatory, normative and cognitive institutional dimensions.

To develop the country scores of each institutional dimension, we utilized data obtained from The World Competitiveness Yearbook published by the International Institute for Management Development (IMD 1999, 2000, 2001, 2002, 2003). First, we selected reports from the years between 1999 and 2003 to calculate the average value across this period. Following previous studies (e.g., Gaur and Lu 2007; Gaur et al. 2007), we organized a panel of three academic experts who were knowledgeable about institutional theory but who were not associated with this research, to select data items from IMD's World Competitiveness Yearbook as indicators for regulatory, normative and cognitive institutions. A prerequisite for any item to be included in this group was that it had to remain present consistently in the data across all 5 years. Then, a factor analysis was conducted to ensure that these items could work as a group to represent the value of regulative, normative and cognitive institutions (see Table 2).

\section{Regulative Institutions}

After checking the IMD data and discussing them with the experts, ten items were selected from the data to represent the legal aspect of a country's institutions. After running the factor analysis, we selected nine items to represent regulative institutions. The Cronbach's alpha for 2002 data was 0.93 . To ensure the data has good reliability, we further tested the Cronbach's alpha's on the data for the remaining 4 years, and the result for each year was above 0.90 .

\section{Cognitive Institutions}

Five items were chosen to represent the belief systems and cultural frames of the institutions, and factor analysis on the 2002 data showed good consistency with Cronbach's alpha for 0.80 . As with the other two institutional dimensions, we further tested the reliability of this measurement for the rest of the years, and they each achieved Cronbach's alpha above 0.80 .

\section{Normative Institutions}

Twelve items were chosen to represent the norms and values aspect of the institutions. Nine items remained in the selection after running the factor analysis, and the Cronbach's alpha value for 2002 data is 0.92 . To ensure the data has good reliability, we further tested the Cronbach's alpha on the data for the remaining 4 years, and the result for each year was above 0.90 .

\section{Calculating Institutional Distance}

First we calculated country scores for each of the 37 host countries using their corresponding scores for regulative, normative and cognitive institutions. These scores are based on a 5-year average (see Table 3).

There are multiple ways to measure institutional distance (e.g., Gaur et al. 2007), and each kind of measurement may have its own shortcomings. In this study, we 


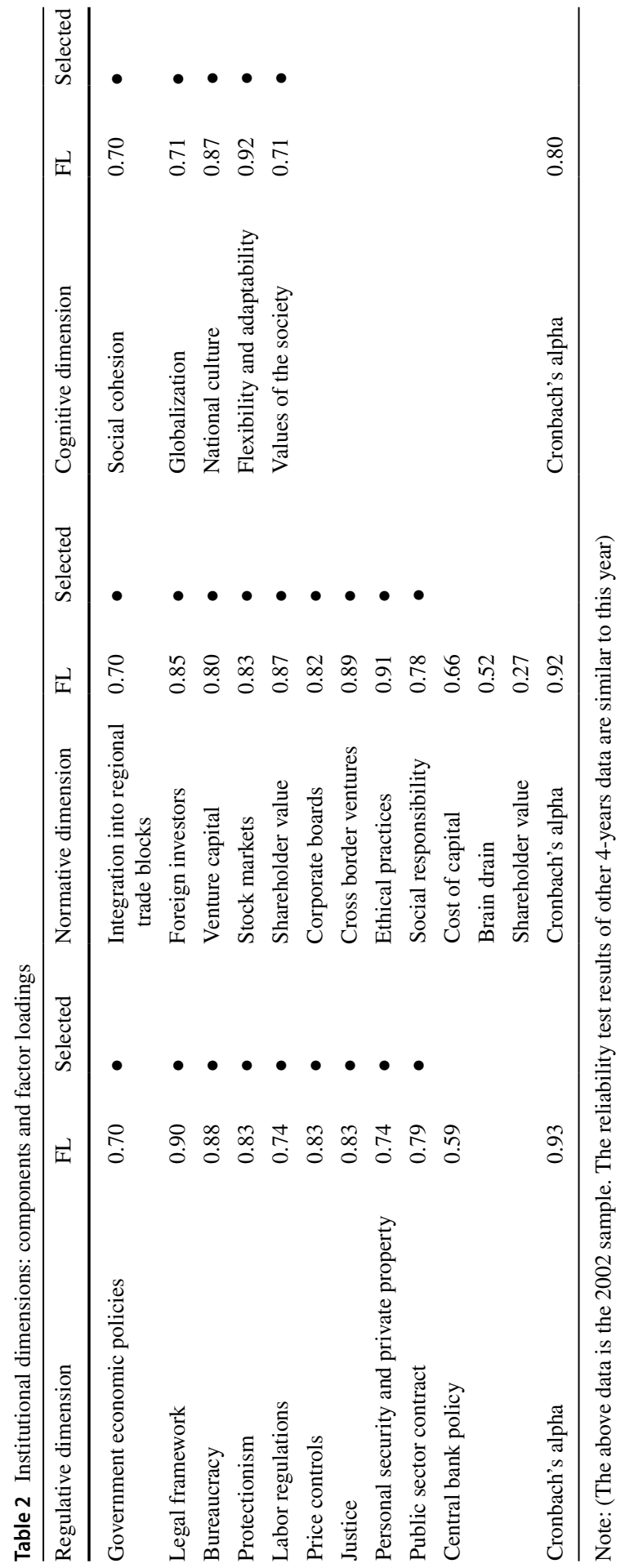


observe the whole subsidiary network of each EFBG, not just the individual headquarter-subsidiary relations (Ghoshal and Bartlett 1990). Observing the whole network of foreign subsidiaries can be helpful to provide the entire picture of the relationships existing among the subsidiaries (Manev 2003; Manev and Stevenson 2001). In other words, subsidiaries are organized according to the need of the whole business group rather than in isolation. The network view assumption fits well with the way in which family ownership controls and then manages the business.

To observe the whole network, we need to determine the relative institutional distances between subsidiary-subsidiary dyads in a business group year-by-year (Manev 2003; Manev and Stevenson 2001). We started off by calculating the relative institutional distance between the headquarter and subsidiaries. For example, if there are two subsidiaries located in the U.S.A. and China (Subsidiary A and B) respectively, we first calculate the relative institutional distances between Taiwan (Headquarters, HQ)-USA (Subsidiary A), and Taiwan (Headquarters, HQ)-China (Subsidiary B). Using these two scores of institutional distances (HQ-A and HQ-B), squaring them, we then recalculate and obtain the relative institutional distances between Subsidiaries A and B in the subsidiary-pair matrix. Previous studies show the square term can be used to derive an absolute difference, which is needed in our case, and to postulate an exponential function between the distance score and the dependent variables (Farh et al. 1998; Tsui and O'Reilly 1989).

\section{Home-Region Oriented EFBGs}

Following the definition of Rugman and colleagues (Rugman and Verbeke 2004), we calculate the revenue of EFBGs and how it is distributed in order to determine whether they are focusing on the home region (i.e., Asian region). Building on Rugman's work, we then categorize these EFBGs as either home-region oriented (with more than $50 \%$ of the revenue from the home region) and coded as " 0 ", or nonhome-region oriented (with more than $50 \%$ of the revenue from outside the home region) and coded as " 1 ". Although the classification of regional focus by utilizing a dummy-coded variable has been criticized as somehow arbitrary, it is hard to justify this variable by adding one or two standard deviations above/below mean since it will create more than one dummy-coded variable and unnecessarily increase the complexity of the overall analysis. Performance of foreign affiliations can be assessed in a number of ways (e.g., Brouthers 2013; Errunza and Senbet 1984; Zahra 2003). According to the data, we chose the foreign affiliation sales as a proxy to measure the foreign affiliation's international performance (Errunza and Senbet 1984; Zahra 2003) and accordingly to identify whether this EFBG is home-region oriented. As the revenue of each FBG is subject to change, we calculate the number of home- and non-home-regionally oriented EFBGs year-by-year. As a result, the total numbers of home and non-home regionally-oriented EFBGs is inconsistent with the number of total EFBGs.

\subsubsection{Control Variables}

We employed a total of 11 control variables in the analysis (see Appendix 1). Following suggestions from previous literature, we used two characteristics at the 
Table 3 Country scores on the three institutional dimensions

\begin{tabular}{|c|c|c|c|}
\hline Country & Regulatory score & Normative score & Cognitive score \\
\hline Australia & 7.3 & 6.75 & 7.24 \\
\hline Austria & 7.07 & 7.06 & 6.83 \\
\hline Belgium & 5.60 & 6.86 & 6.82 \\
\hline Brazil & 4.95 & 5.64 & 7.09 \\
\hline Canada & 7.12 & 7.28 & 7.33 \\
\hline Chile & 6.46 & 6.83 & 7.22 \\
\hline China & 4.84 & 5.19 & 5.67 \\
\hline Czech & 5.09 & 5.06 & 6.02 \\
\hline Denmark & 7.57 & 7.54 & 6.89 \\
\hline Finland & 8.15 & 8.08 & 7.65 \\
\hline France & 5.37 & 6.5 & 5.48 \\
\hline Germany & 6.41 & 7.08 & 6.15 \\
\hline Hong Kong & 7.49 & 7.21 & 7.58 \\
\hline Hungary & 5.69 & 5.71 & 6.23 \\
\hline India & 4.97 & 4.7 & 6.04 \\
\hline Indonesia & 3.86 & 4.84 & 5.42 \\
\hline Ireland & 7.31 & 7.3 & 7.52 \\
\hline Israel & 6.20 & 6.46 & 7.02 \\
\hline Italy & 4.57 & 5.65 & 6.14 \\
\hline Japan & 5.13 & 5.18 & 5.53 \\
\hline Korea & 4.60 & 5.24 & 5.95 \\
\hline Luxembourg & 7.2 & 7.39 & 7.15 \\
\hline Malaysia & 6.12 & 6.05 & 6.83 \\
\hline Mexico & 4.65 & 5.66 & 6.17 \\
\hline Netherlands & 7.12 & 7.78 & 7.76 \\
\hline New Zealand & 7.50 & 6.88 & 7.14 \\
\hline Norway & 6.87 & 6.53 & 6.44 \\
\hline Philippines & 4.71 & 5.39 & 6.39 \\
\hline Poland & 4.04 & 4.48 & 5.27 \\
\hline Portugal & 5.38 & 5.92 & 6.46 \\
\hline Singapore & 8.09 & 7.42 & 7.79 \\
\hline Spain & 5.99 & 6.4 & 6.33 \\
\hline Sweden & 7.03 & 7.56 & 6.87 \\
\hline Switzerland & 6.75 & 6.72 & 6.75 \\
\hline Thailand & 5.55 & 5.54 & 6.18 \\
\hline United States & 6.63 & 7.41 & 7.61 \\
\hline United Kingdom & 6.67 & 6.96 & 6.35 \\
\hline
\end{tabular}

Note: 1 . The IMD database excludes some countries' information that the business groups in Taiwan are invested, including Samoa, Vietnam, Costa Rica, United Arab Emirates, Jordan, and Panama

Note 2. The above score data is calculated by averaging the data over 5-years. However, the distance scores in the analytic models are a 1-year data for each business group over the 5-years 
business-group level, Group's Asset and Group's Age, to control for their potential impact on the decision regarding the selection of heads of subsidiaries (Belderbos and Heijltjes 2005; Khanna and Rivkin 2001). We controlled for the possible influence of founding family leadership by utilizing a dummy-coded variable Founder Leadership to indicate whether EFBGs are led by the generation of the founder (" 1 " indicates the founder still serves as the CEO or in a chair position in the EFBGs, whereas it is " 0 "). Previous studies highlight family business groups with founding family leadership which may provide a unique governance environment that offers lower agency costs and higher performance (Steier 2003). Additionally, we used Family Members in the Inner Circle to control for the influence of family ownership on the selection of heads of subsidiaries. The Inner Circle is defined as the set of leaders with decision-making power in business groups (Chung and Luo 2008). Studies suggest that the more family members who occupy the inner circle in a family business group, the more likely the family is to control the strategic direction of this business group (Luo and Chung 2005). As such, it is more likely for EFBGs to assign family members to serve in key strategic-decision roles in foreign subsidiaries. We utilized the CCIS database and other secondary data to determine the ratio of family members within the Inner Circle of the EFBGs.

Moreover, two control variables on the level of family business groups are used to control for the international experience of EFBGs. We use Network Size to control the maturity of the foreign operations for a particular EFBG. The size of the network is measured by the number of subsidiaries-pairs located in an EFBG, e.g., the number of the network size is 1 for an EFBG with two subsidiaries, while the number of the network size will be 4 when an EFBG has three subsidiaries. As the number of subsidiaries increases, the scale and importance of an EFBG's foreign operations also become more substantial (Kilduff and Tsai 2003). When an EFBG has a larger network of subsidiaries aboard, family members may not be needed as its foreign operations are relatively matured. Following the measurement in previous studies (Hitt et al. 1997), we also control the distinctive foreign sales in each regional market (e.g., Asia Pacific, America, Europe, and Africa) to calculate the Level of International Diversification of each EFBG year by year. The measurement takes into consideration the relative importance of foreign sales in each regional market (Hitt et al. 1997).

Lastly, we employed five subsidiary-level characteristics as control variables. We controlled for Subsidiary Country Similarity, and Subsidiary Industry Similarity, with both being dummy variables (Manev 2003). They were coded "1" if two subsidiaries belong to the same country and 2-digit industry code, otherwise they were coded "0". We further controlled for Subsidiary Age Similarity, and Subsidiary Asset Similarity, and they were measured by utilizing the distance measurement method introduced above (Farh et al. 1998; Tsui and O'Reilly 1989) to measure the paired subsidiaries' age- and asset-distance based on information from the CCIS database and secondary data. The smaller the age- or asset- distances, the more similar the characteristics were determined to be. Finally, we controlled for the GDP Similarity of the host countries, which indicates the relative importance of the market and future potential consumption capability. This variable is also measured by the 
GDP-distance of the embedded country in the paired subsidiaries. This data was obtained from the World Bank.

\subsection{Data Analysis}

This study employs a Multi-level, Mixed-effects Linear Model (Logit model) run by STATA 9.0 software. This is considered appropriate when the data is characterized by both random effects from the business group-level variables (the context) and fixed effects from the independent variables in the lower level (Peterson et al. 2012; Rabe-Hesketh and Skrondal 2012). As our model intends to understand a business group's decision to appoint a family member as subsidiary head at the lower level (i.e., subsidiaries), and how this decision is affected by the dissimilarity in institutional context between host and home countries, a Multilevel, Mixed-effects Linear Model is deemed suitable for our analysis. Additionally, since we assume family members are limited in number and their deployment is a strategic decision taken by EFBGs among all potential subsidiaries, our analytical model runs on paired subsidiaries and compares institutional distance between home country and each subsidiary in the pair. We follow Manev and Stevenson (2001) and use the difference in family membership status as the basis for an analysis of the dependent variable. Therefore, the level of analysis in this study is the subsidiary-dyad level. Moreover, our data include 4780 foreign subsidiaries, hence the coefficient estimates on each of our variables are not sensitive to the inclusion or exclusion of a particular variable (Gaur et al. 2007).

\section{Results}

Table 4 shows the descriptive statistics and correlations between variables used in this study. Approximately $15 \%$ of the foreign subsidiaries in our sample have family members as their head. Additionally, nearly half of the EFBGs still have the founder serving as the CEO or in a chair position in the FBGs, and on average, family members take up $78 \%$ of the inner circle.

Table 5 presents the results of our five ML models (ML-1 to ML-3), with Family Manager as the dependent variable and Regulative, Normative and Cognitive Institutional Distance as independent variables. Model ML-1 shows the influence of all three institutional distance variables on appointing a family member as the head of subsidiaries in all EFBGs. ML-2 and ML-3 show the effects in the home region and non-home region-oriented EFBGs respectively. Wald chi-square values are found to be significant for all models, and thus, the model-of-fitness and the model setting are reasonably well satisfied. We also test the VIF of all three independent variables (regulative, normative and cognitive institutional distances), and all the VIF are less than 2 in all of the models. As such, there is no potential concern for collinearity coming from the models. 


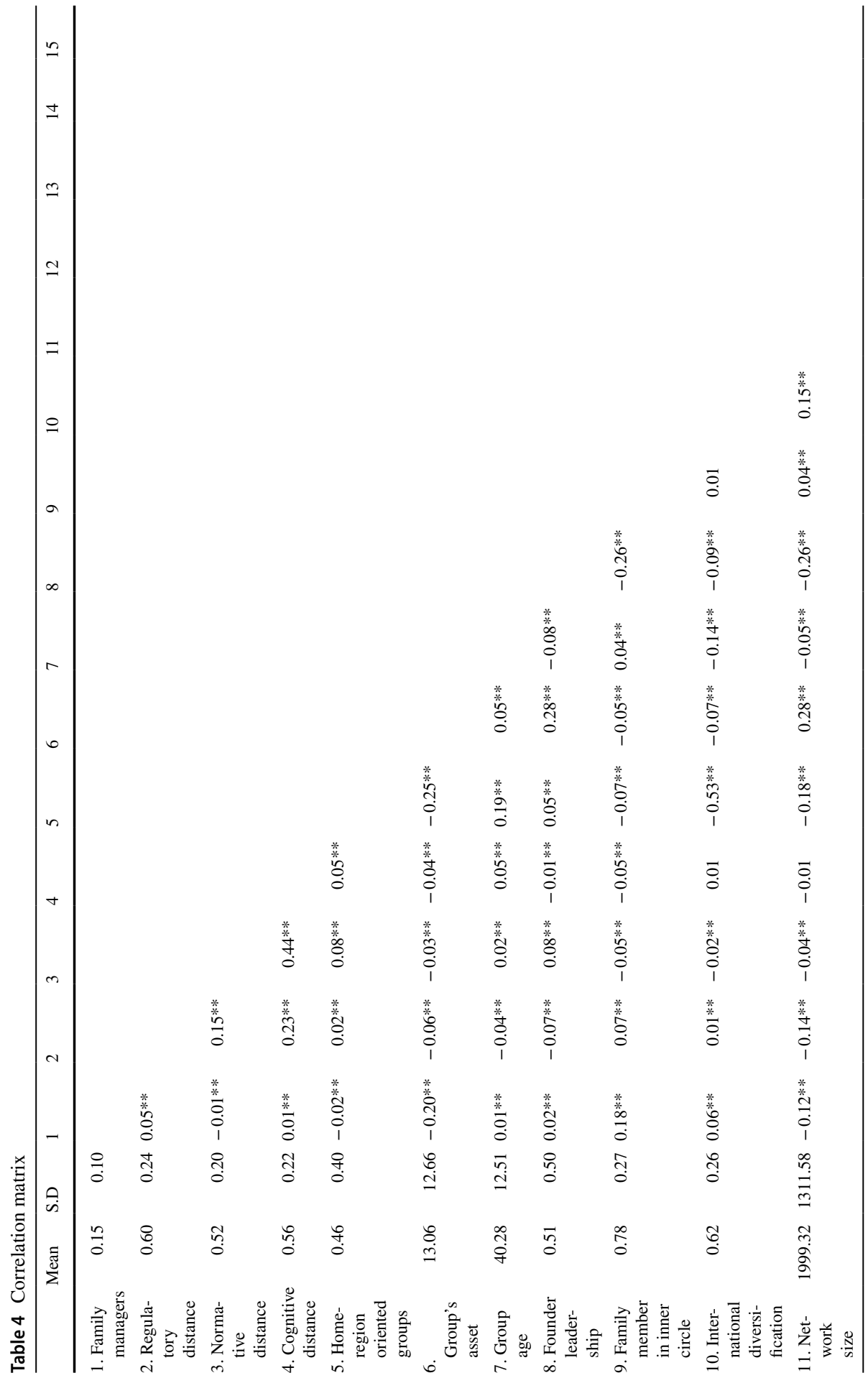




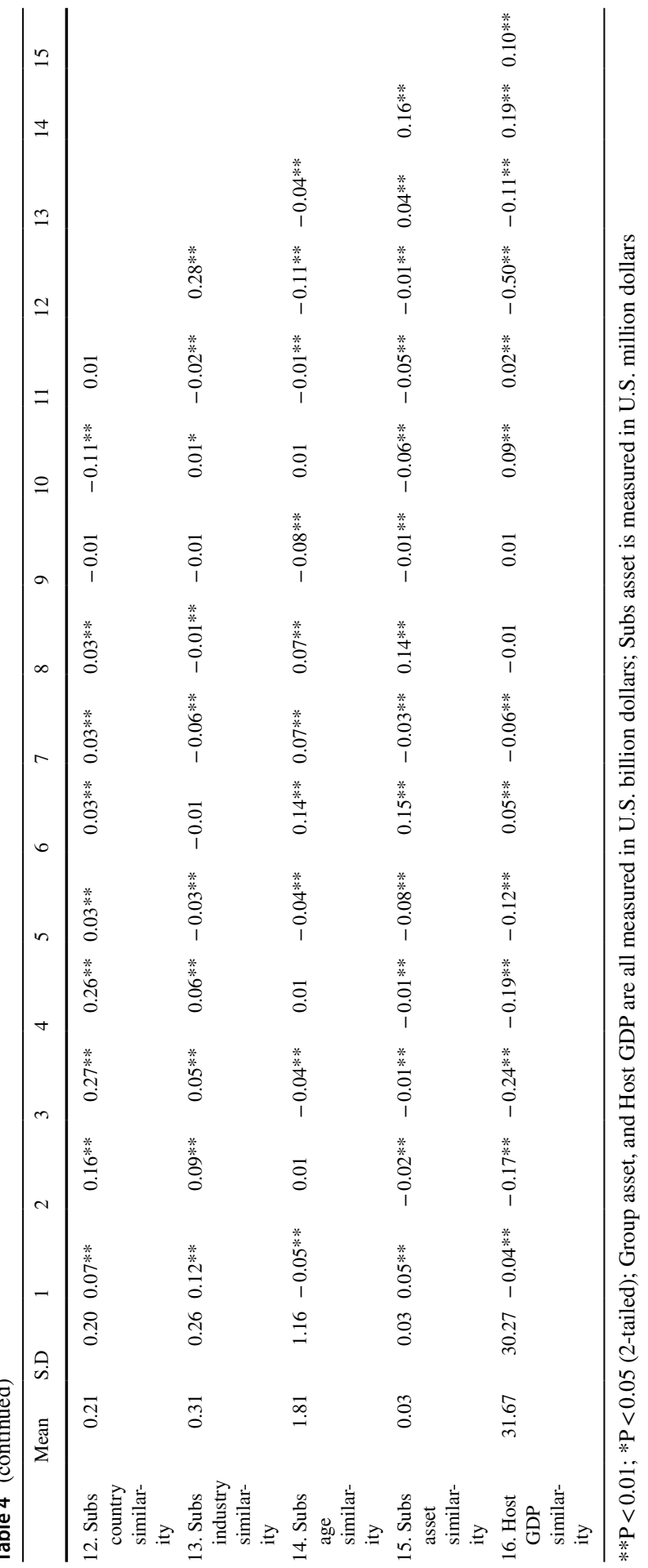




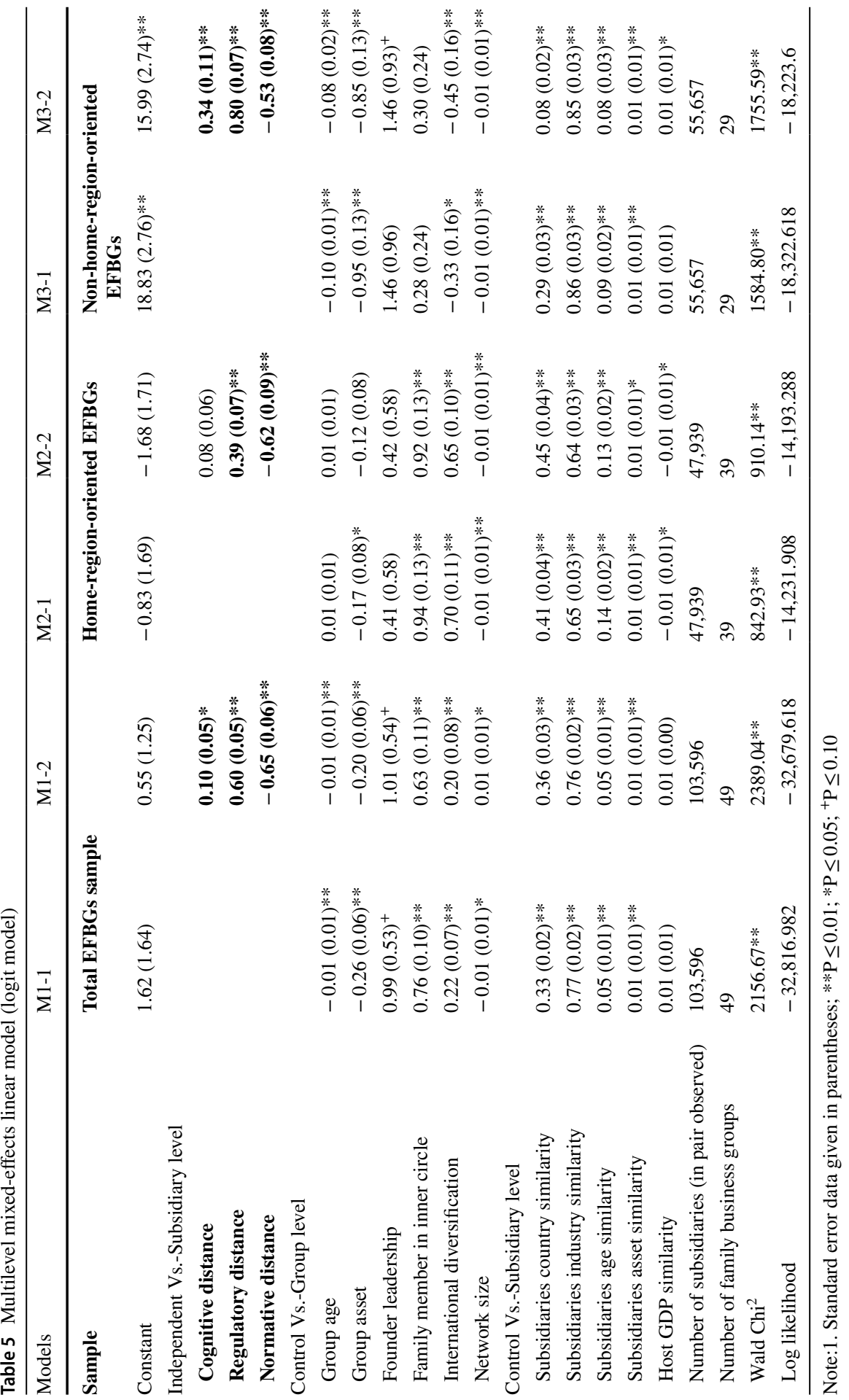


The results of the hypotheses tests are presented in Table 5. The ML-1 model shows support for hypotheses $1 \mathrm{a}$, and $1 \mathrm{~b}$, but not $1 \mathrm{c}$. Regulative and cognitive institutional distance both have a positive and significant influence on the likelihood of having a family member as subsidiary head. However, a negative and significant influence from normative institutional distance can also be observed from the results.

To test hypothesis 2, we run the analysis on ML-2 and ML-3. The results indicate that the patterns for regulative and normative institutional distance are the same for both home-region and non-home-region-oriented EFBGs. Yet, the results show the effect of institutional distance on FEBGs does not have a home-region orientation that is much stronger than in the case of home-region-oriented EFBGs. Moreover, for cognitive-institutional distance, only EFBGs that focus on non-home-region show a significant association. Moreover, one-way ANOVA tests indicate that the differences between these two groups of EFBGs are significant. Therefore, hypothesis 2 is also supported. In other words, EFBGs with focus outside the home region, in contrast to home-region-oriented EFBGs, are more likely to use family managers in foreign subsidiaries located in host countries at a larger institutional distance.

\section{Discussion}

\subsection{The strategic use of family managers in EFBGs internationalization}

Our results show support for our hypotheses and indicate that family managers play a strategic role during the internationalization process of the EFBGs. More specifically, not only do institutional dimensions influence the use of family managers in EFBGs differently, but also that EFBGs with varying regional orientation behave in a dissimilar fashion. A few points of discussion can be made based on these results. Firstly, through the use of family managers and the positioning family members strategically in foreign subsidiaries that are located at a greater institutional distance, EFBGs can maintain trusted management that is agile across national borders and sustain their competitive advantages. This observation is especially prominent in EFBGs that focus outside their home region, as their sales are mostly conducted in countries where significant institutional differences are present. Therefore, family managers can be argued to pertain a dual role in EFBGs (Sirmon and Hitt 2003); it is not just the strong ties or relational contract that binds the family ownership throughout the business groups (Peng and Jiang 2010), they also function as a specific resource that supports efficient coordination and control within the business group network (Carney 2005; Verbeke and Kano 2012, 2016).

Secondly, while institutional pressure from the host countries can force entering firms to avoid strong ownership (Chung and Dahms 2018; Xu et al. 2004), our results show EFBGs still commit to the use of family managers in foreign subsidiaries despite the existence of large regulative- and cognitive- institutional distance. Expanding on Peng and Jiang (2010), our results suggest that institutional and family business group factors play a role not only at the national level, but also influence decision- making between the headquarters and subsidiaries. It is possible that 
dual roles of the family managers, i.e., relational contracting and EFBGs-specific resource, act as a means to mitigate and manage the external institutional pressure that EFBGs are exposed to in the host country. Especially, EFBGs can overcome institutional distance and demonstrate "the ability to engage in behavior deviating from the standard in a particular host setting" (Fortwengel 2017: p. 795). Our study therefore can contribute significantly to the continuing discussions on institutional distances and of internationalization strategy.

Our study also shows that normative institutions affect the internationalization behavior of the EFBGs differently in comparison to regulative and cognitive institutions. It seems that EFBGs are less likely to utilize family managers when normative-institutional distance in the foreign subsidiaries is greater. Normative institutions are argued to have a stronger bearing on a foreign subsidiary's ability to achieve legitimacy in the host country (Miller et al. 2017; Xu and Shenkar 2002), which may severely impact their survivability and success rate. Unlike regulative and cognitive institutions, normative institutions are about how actions should be carried out within the society. We suspect greater difficulties may be present for family members in observing and learning normative-institutional differences effectively. As normative institutions are based on the appropriateness (Edwards et al. 2019; Scott 1995), a foreign individual ought to identify the difference and then behave in an appropriate manner. Therefore, foreign subsidiaries facing normative institutional pressure may focus more on how to behave similar to local actors to avoid the label of foreignness (Ahworegba 2018). Past literature indicates that EFBGs are well aware of the limitations (Luo and Chung 2013), and can select an appropriate method of control accordingly. As a result, EFBGs may be discouraged to intervene, and therefore may choose not to send family members.

Lastly, we also provide insights to the regionalization argument (Rugman and Verbeke 2005). Our results indicate that EFBGs develop managerial mechanisms to deal with regional outsidership (Johanson and Vahlne 2009; Vahlne and Johanson 2017). In our case, we identified the selective use of family managers for EFBGs with a different focus, which strengthens our argument that family managers function as a specific rare resource to EFBGs. That shows that EFBGs' heterogeneity, in our case defined as their regional focus, matters in the way they are affected by institutional distance in their choice of selecting family managers to act as head of their subsidiaries.

\subsection{EFBGs vs. family business and family business groups from elsewhere}

Although we lack a precise comparison between EFBGs with other types of firms in regard to their internationalization behavior, e.g., family businesses (Del Bosco and Bettinelli 2020; Vandekerkhof et al. 2015), or business groups (Gaur et al. 2007, 2019) from elsewhere, our findings remain consequential.

EFBGs and family businesses share great communalities. For instance, they are both averse to outsider influence, and prefer debt financing instead of equity (Arregle et al. 2017). Most importantly, both emphasize family wealth rather than profit maximization (Arregle et al. 2007; Gómez-Mejía et al. 2007; Daspit et al. 
2018). From a historical perspective, some literature has even suggested that family business groups and family businesses in general share a common ancestry in how the business is structured (Khanna and Yafeh 2007).

Yet, research on the distinction between family business groups and family businesses is still in its infancy (Rosa et al. 2019). What differentiates EFBGs from family businesses the most is the complexity of decision-making process-whether it is due to their structure, ownership, or interaction with society (Khanna and Yafeh 2007), or as an evolving system that is influenced by their adaptivity, self-organization and emergence (Mukherjee et al. 2019). EFBGs are considerably more diverse horizontally and vertically than family businesses due to the large number of legally independent affiliations interconnected via family ownership (Pihkala et al. 2019). Unlike the family business that can be rather narrowly focusing on certain lines of business, EFBGs require a greater managerial capacity to strategically process information and coordinate business activities (Zellweger 2017). Family managers are likely to be more instrumental for the internationalization of EFBGs since they not only provide relational contracts but also firm-specific resources that are crucial for strategic management. Additionally, if we consider that many EFBGs have evolved from small family businesses (Khanna and Yafeh 2007), it is quite clear that certain behavior traits may remain the same. Nevertheless, we believe that our results can provide also insights for large family businesses, since their shared ancestorship and the potential of sharing similar magnitudes of decision-making complexity.

The distinction between EFBGs from Taiwan, and EFBGs from other emerging markets, and even family business groups from developed economies is further complicated by the absence of the broader empirical literature (Rosa et al. 2019). For instance, while studies by Gaur and Kumar (2009), Gaur and Delios (2015), and Gaur et al. (2019) examine business groups in India and South Korea and mention that "most" business groups in these respective countries are owned by families, no further distinction has been made in discussing the results and implications for family business groups. This shortcoming may be due to methodological challenges in defining family business groups (Rosa et al. 2019), as well as the missing opportunity to conceptualize the advantage (and disadvantage) for having family ownership (Mukherjee et al. 2019). As a result, there are rather limited comparable studies between EFBGs from various emerging markets and family business groups from advanced economies.

Therefore, what might differentiate emerging market family business groups (e.g., Taiwanese EFBGs) from their counterparts located in the advanced economies is likely to be the institutional environment of their home countries where institutions can be weak, less stable or even absent (Khanna and Palepu 2000; Peng 2013). It is also important to note that some EFBGs tend to be nurtured and supported by their home government (Carney and Gedajlovic 2002; Khanna and Yafeh 2007). For example, family business groups from emerging markets are known to rely upon or even extract government resources and receive support or even protection from government policies (Carney et al. 2018; Khanna and Yafeh 2007). EFBGs developed from this context may tend to have a stronger experience dealing with regulative actors, and that can well explain the observations of Taiwanese EFBGs made in our study having a pronounced strategy to use family mangers in regulative distant 
host countries. Family managers may be a preferable choice by Taiwanese EFBGs to deal with the host government rather than locally hired managers as the formers are part of the family (Wan and Hoskisson 2003). In contrast, family business groups from advanced economies with strong institutions e.g., the Nordic European region, which received comparatively less support from the government may not have the same scale of dependence on family managers for foreign expansion (Piana et al. 2018).

Nevertheless, we would still expect the generalizability of our findings not to be significantly influenced by the origins of the family business group. The general emphasis that family business groups have is the promotion of family values and family wealth maximization, and it is inevitable that family members are involved in decision-making activities and the responsibility to various degrees (Carney 1998; Carney and Gedajlovic 2002; Deephouse and Jaskiewicz 2013; Daspit et al. 2018; Gómez-Mejía et al. 2007; Piana et al. 2018; Pihkala et al. 2019). Purkayastha et al. (2017) show that family ownership in Indian business groups can be beneficial at the beginning of the internationalization, and Hernández et al. (2018) find family ownership may encourage Italian family business to select more risky international markets to invest. Our study is consistent with the arguments put forward by Miller and Le Breton-Miller (2006) in that the use of trust as a firm-specific resource may be exploited in uneven institutional terrain, and represents a key feature found in family businesses and family business groups around the world. Arguably, family business groups are not homogenous, and we have found that is certainly the case for Taiwanese FBGs. Hence, family involvement including the use of family managers will be based on the strategic demand from various sides of the business groups.

Lastly, the insights gained from our study could also apply to non-family business groups because some follow an ethnocentric staffing approach. For example, business groups from Japan show a tendency to use Japanese managers in key positions in order to facilitate knowledge and practice transfer (Conrad and Meyer-Ohle 2019; Gaur and Lu 2007). In that way, our findings complement Gaur et al. (2007) who found that greater institutional distance leads Japanese firms to employ Japanese directors in their subsidiaries. Our study extends their findings in that we add the notion that the regional orientation of the firm also impacts such decision making.

\section{Conclusions}

In this study we set out to answer the questions of how institutional distances affect the EFBGs' use of family managers when operating in foreign markets, and how that is in turn affected by their heterogeneity in regional focus. We argued EFBGs use family managers as a unique EFBGs'-specific resource in internationalization to mitigate institutional distance effects between home and host country. Our results support this argument when foreign subsidiaries are located in countries at a greater regulative- and cognitive-institutional distance. However, we also found that they refrain from doing so when faced with cases involving larger normative institutional distance. Furthermore, EFBGs with a focus outside the home region, due to their sales being generally distributed in countries with greater institutional differences, 
are more likely to use family managers than do their counterparts. Our study contributes to the continuing investigation of the impact of institutional distance on the internationalization behavior of the multinational enterprise, as well as advancing the overall understanding of EFBGs located internationally.

\subsection{Limitations and Future Research}

As with any research, this study has limitations that could point towards fruitful future research directions. Even though the Taiwanese EFBGs in our sample belong to the Top-100 business groups in the country, this study does not include any explicit performance measurement. Instead, we place our emphasis on the relation between institutional distance and the use of family managers, and do not investigate whether this helps EFBGs and their foreign subsidiaries deliver better results. Future studies can extend our results to investigate this matter. Additionally, although the choice of EFBGs from Taiwan is justified given that previous international business research has predominantly investigated advanced-economy samples (Edwards et al. 2019), and family business groups as a whole are of growing importance in the world economy (Bannò and Sgobbi 2016; Vandekerkhof et al. 2015); it would be interesting to see if our results also hold in other countries. Especially family business groups from different parts of the world may not have the same ownership style due to the social, cultural and institutional context they are embedded in. Family business groups from a certain region may have experienced modernization or capacity development (Carney 2005; Carney et al. 2018), which can have an impact on how they use family members in key positions, and even regarding the succession plan yet to be implemented. Future studies can look into regional variations, as well as the stage of development in family business groups in relation to the use of family managers in foreign subsidiaries. In addition, it might well be that some family managers are sent abroad to head subsidiaries as a kind of punishment. For instance, it might well be that some locations might be more desirable than others and that for internal reasons some family managers are transferred to less desirable locations. Furthermore, it might also be the case that some subsidiaries have had family members assigned previously due to a number of other reasons such as tradition or a history of the subsidiary. However, our data is unable to capture such intricacy.

\subsection{Managerial Relevance}

The results of our study also provide valuable managerial implications for the decisions EFBGs make regarding whether or not to send family members overseas to lead their subsidiaries. First, EFBGs need to be aware that not every aspect of institutions impacts the groups in the same way, and the use of family members in foreign subsidiaries is not a straight-forward control mechanism to overcome all of the challenges faced in foreign operations. Although the use of family managers in foreign subsidiaries has the distinct advantage of extending family values and transferring knowledge, the competitive advantage created by using family managers may be restricted to certain institutional conditions in the host country. While it may 
be sufficient to use family members to strengthen the connections between foreign subsidiaries and headquarter when there are greater dissimilarities in regulative and cognitive institutions in the host countries, it may not work as well in terms of normative-institutional distance. Therefore, our results seem to indicate that the use of family managers as a control mechanism is possibly interwoven into the institutional logic already embedded in a given society.

\section{Appendix 1: List of control variables}

\begin{tabular}{|c|c|c|c|c|}
\hline Variable & Characteristic & Measurement & Control level & Source \\
\hline $\begin{array}{l}\text { Control 1: Group } \\
\text { asset }\end{array}$ & $\begin{array}{l}\text { The asset the } \\
\text { EFBG owns }\end{array}$ & \$ (USD) & Group level & $\begin{array}{l}\text { CCIS and secondary } \\
\text { data }\end{array}$ \\
\hline $\begin{array}{l}\text { Control 2: Group } \\
\text { age }\end{array}$ & $\begin{array}{l}\text { The age of the } \\
\text { EFBG }\end{array}$ & Number of year & Group level & $\begin{array}{l}\text { CCIS and secondary } \\
\text { data }\end{array}$ \\
\hline $\begin{array}{l}\text { Control 3: Founder } \\
\text { leadership }\end{array}$ & $\begin{array}{l}\text { Whether the } \\
\text { founder still } \\
\text { serves as the } \\
\text { CEO or chair } \\
\text { position }\end{array}$ & $\begin{array}{l}\text { Dummy variable } \\
\quad(\text { Yes-1/No-0) }\end{array}$ & Group level & $\begin{array}{l}\text { CCIS and secondary } \\
\text { data }\end{array}$ \\
\hline $\begin{array}{l}\text { Control 4: Family } \\
\text { member in inner } \\
\text { circle }\end{array}$ & $\begin{array}{l}\text { Percentage of fam- } \\
\text { ily member is in } \\
\text { the inner circle }\end{array}$ & Percentage $(\%)$ & Group level & $\begin{array}{l}\text { CCIS and secondary } \\
\text { data }\end{array}$ \\
\hline $\begin{array}{l}\text { Control 5: Interna- } \\
\text { tional diversifica- } \\
\text { tion }\end{array}$ & $\begin{array}{l}\text { The extent of sales } \\
\text { outside domestic } \\
\text { market and their } \\
\text { global distribu- } \\
\text { tion (in regional } \\
\text { level) }\end{array}$ & Number score & Group level & $\begin{array}{l}\text { CCIS and secondary } \\
\text { data }\end{array}$ \\
\hline $\begin{array}{l}\text { Control 6: Network } \\
\text { size }\end{array}$ & $\begin{array}{l}\text { The scale and } \\
\text { intensity of } \\
\text { subsidiaries in } \\
\text { foreign countries }\end{array}$ & $\begin{array}{l}\text { Numbers foreign } \\
\text { subsidiary (in } \\
\text { pairs) from the } \\
\text { EFBG }\end{array}$ & Group level & $\begin{array}{l}\text { CCIS and secondary } \\
\text { data }\end{array}$ \\
\hline $\begin{array}{l}\text { Control 7: Sub- } \\
\text { sidiaries country } \\
\text { similarity }\end{array}$ & $\begin{array}{l}\text { Whether subsidiar- } \\
\text { ies are located in } \\
\text { the same country }\end{array}$ & $\begin{array}{l}\text { Dummy vari- } \\
\text { able (same coun- } \\
\text { try-1/no-0) }\end{array}$ & Subsidiary level & $\begin{array}{l}\text { CCIS and secondary } \\
\text { data }\end{array}$ \\
\hline $\begin{array}{l}\text { Control 8: Sub- } \\
\text { sidiaries industry } \\
\text { similarity }\end{array}$ & $\begin{array}{l}\text { Whether subsidiar- } \\
\text { ies are located in } \\
\text { the same industry }\end{array}$ & $\begin{array}{l}\text { Dummy variable } \\
\text { (same indus- } \\
\text { try-1/no-0) }\end{array}$ & Subsidiary level & $\begin{array}{l}\text { CCIS and secondary } \\
\text { data }\end{array}$ \\
\hline $\begin{array}{l}\text { Control 9: Sub- } \\
\text { sidiaries age } \\
\text { similarity }\end{array}$ & $\begin{array}{l}\text { Difference in age } \\
\text { between subsidi- } \\
\text { aries }\end{array}$ & Year & Subsidiary level & $\begin{array}{l}\text { CCIS and secondary } \\
\text { data }\end{array}$ \\
\hline $\begin{array}{l}\text { Control 10: Sub- } \\
\text { sidiaries asset } \\
\text { similarity }\end{array}$ & $\begin{array}{l}\text { Difference in asset } \\
\text { between subsidi- } \\
\text { aries }\end{array}$ & \$ (USD) & Subsidiary level & $\begin{array}{l}\text { CCIS and secondary } \\
\text { data }\end{array}$ \\
\hline $\begin{array}{l}\text { Control 11: Sub- } \\
\text { sidiaries country } \\
\text { GDP similarity }\end{array}$ & $\begin{array}{l}\text { Difference in GDP } \\
\text { between the } \\
\text { countries where } \\
\text { subsidiaries } \\
\text { located }\end{array}$ & \$ (USD) & Subsidiary level & The World Bank \\
\hline
\end{tabular}


Author contributions Authors are arranged in the alphabetical order of their surname. All authors contributed to this study equally. All authors read and approved the final manuscript.

Funding Open Access funding provided by Uppsala University. The authors greatly appreciate the sponsorship provided to this study by Ministry of Science and Technology, Executive Yuan, Taiwan, under Grant Number: MOST106-2410-H-214-007-MY3, 2017/08-2020/07.

Open Access This article is licensed under a Creative Commons Attribution 4.0 International License, which permits use, sharing, adaptation, distribution and reproduction in any medium or format, as long as you give appropriate credit to the original author(s) and the source, provide a link to the Creative Commons licence, and indicate if changes were made. The images or other third party material in this article are included in the article's Creative Commons licence, unless indicated otherwise in a credit line to the material. If material is not included in the article's Creative Commons licence and your intended use is not permitted by statutory regulation or exceeds the permitted use, you will need to obtain permission directly from the copyright holder. To view a copy of this licence, visit http://creativecommons.org/licen ses/by/4.0/.

\section{References}

Ahworegba, A. H. (2018). The dilemma of institutional duality and multinational firms 1967-2017: Implications and future research. Multinational Business Review, 26(2), 145-172.

Ambos, T. C., \& Ambos, B. (2009). The impact of distance on knowledge transfer effectiveness in multinational corporations. Journal of International Management, 15(1), 1-14.

Ando, N., \& Paik, Y. (2013). Institutional distance, host country and international business experience, and the use of parent country nationals. Human Resource Management Journal, 23(1), 52-71.

Arregle, J.-L., Duran, P., Hitt, M. A., \& Van Essen, M. (2017). Why is Family Firms' Internationalization Unique? A Meta-Analysis. Entrepreneurship Theory and Practice, 41(5), 801-831.

Arregle, J.-L., Hitt, M. A., Sirmon, D. G., \& Very, P. (2007). The development of organizational social capital: Attributes of family firms. Journal of Management Studies, 44(1), 73-95.

Bannò, M., \& Sgobbi, F. (2016). Family business characteristics and the approach to HRM in overseas ventures. Journal of Small Business Management, 54(2), 640-658.

Barney, J. B. (1986). Strategic factor markets: Expectations, luck, and business strategy. Management Science, 32(10), 1231-1241.

Barney, J. B. (1991). Firm resources and sustained competitive advantage. Journal of Management, 17(1), 99-120.

Belderbos, R. A., \& Heijltjes, M. G. (2005). The determinants of expatriate staffing by Japanese multinationals in Asia: Control, learning and vertical business groups. Journal of International Business Studies, 36(3), 341-354.

Berrone, P., Cruz, C., \& Gómez-Mejía, L. R. (2012). Socioemotional wealth in family firms: Theoretical dimensions, assessment approaches, and agenda for future research. Family Business Review, 25(3), 258-279.

Beugelsdijk, S., Ambos, B., \& Nell, P. C. (2018). Conceptualizing and measuring distance in international business research: Recurring questions and best practice guidelines. Journal of International Business Studies, 49(9), 1113-1137.

Bian, Y. (1997). Bringing strong ties back in: Indirect ties, network bridges, and job searches in China. American Sociological Review, 62(3), 366-385.

Brouthers, K. D. (2013). A retrospective on: Institutional, cultural and transaction cost influences on entry mode choice and performance. Journal of International Business Studies, 44(1), 14-22.

Carney, M. (1998). A management capacity constraint? Obstacles to the development of the overseas Chinese family business. Asia Pacific Journal of Management, 15(2), 137-162.

Carney, M. (2005). Corporate governance and competitive advantage in family-controlled firms. Entrepreneurship Theory and Practice, 29(3), 249-265.

Carney, M., Dieleman, M., \& Taussig, M. (2016). How are institutional capabilities transferred across borders? Journal of World Business, 51(6), 882-894. 
Carney, M., \& Gedajlovic, E. (2002). The co-evolution of institutional environments and organizational strategies: The rise of family business groups in the ASEAN region. Organization Studies, 23(1), 1-29.

Carney, M., Van Essen, M., Estrin, S., \& Shapiro, D. (2018). Business groups reconsidered: Beyond paragons and parasites. Academy of Management Perspectives, 32(4), 493-516.

Certo, S. T., \& Semadeni, M. (2006). Strategy research and panel data: Evidence and implications. Journal of Management, 32(3), 449-471.

Chang, S. (2006). Business groups in East Asia: Financial crisis, restructuring, and new growth. Oxford: Oxford University Press on Demand.

China Credit Information Service. (2001). 2001 Business Groups in Taiwan. Taipei: China Credit Information Service.

China Credit Information Service. (2002). 2002 Business Groups in Taiwan. Taipei: China Credit Information Service.

China Credit Information Service. (2003). 2003 Business Groups in Taiwan. Taipei: China Credit Information Service.

China Credit Information Service. (2004). 2004 Business Groups in Taiwan. Taipei: China Credit Information Service.

China Credit Information Service. (2005). 2005 Business Groups in Taiwan. Taipei: China Credit Information Service.

Chrisman, J. J., Chua, J. H., \& Kellermanns, F. (2009). Priorities, resource stocks, and performance in family and non-family firms. Entrepreneurship Theory and Practice, 33(3), 739-760.

Chung, C.-N. (2001). Markets, culture and institutions: The emergence of large business groups in Taiwan, 1950s-1970s. Journal of Management Studies, 38(5), 719-745.

Chung, C.-N., \& Luo, X. (2008). Institutional logics or agency costs: The influence of corporate governance models on business group restructuring in emerging economies. Organization Science, 19(5), 766-784.

Chung, H.-M. (2014). The role of family management and ownership on semi-globalization pattern of globalization: The case of family business groups. International Business Review, 23(1), $260-271$.

Chung, H.-M., \& Dahms, S. (2018). Ownership strategy and foreign affiliate performance in multinational family business groups: A double-edged sword. Journal of International Management, 24(4), 303-316.

CIA (2018). The World Factbook-Central Intelligence Agency. https://www.cia.gov/library/publi cations/the-world-factbook/geos/tw.html. Accessed 10 Jan 2018.

Conrad, H., \& Meyer-Ohle, H. (2019). Overcoming the ethnocentric firm? Foreign fresh university graduate employment in Japan as a new international human resource development method. The International Journal of Human Resource Management, 30(17), 2525-2543.

Daspit, J. J., Chrisman, J. J., Sharma, P., Pearson, A. W., \& Mahto, R. V. (2018). Governance as a source of family firm heterogeneity. Journal of Business Research, 84, 293-300.

Deephouse, D. L., \& Jaskiewicz, P. (2013). Do family firms have better reputations than non-family firms? An integration of socioemotional wealth and social identity theories. Journal of Management Studies, 50(3), 337-360.

Del Bosco, B., \& Bettinelli, C. (2020). How do family SMEs control their investments abroad? The role of distance and family control. Management International Review, 60(1), 1-35.

DiMaggio, P. J., \& Powell, W. W. (1983). The iron cage revisited: Institutional isomorphism and collective rationality in organizational fields. American Sociological Review, 48(2), 147-160.

Eddleston, K. A., Kellermanns, F. W., \& Sarathy, R. (2007). Resource configuration in family firms: Linking resources, strategic planning and technological opportunities to performance. Journal of Management Studies, 45(1), 26-50.

Eden, L., \& Miller, S. R. (2004). Distance matters: Liability of foreignness, institutional distance and ownership strategy. In Advances in International Management (Vol. 16, pp. 187-221). Bingley: Emerald (MCB UP).

Edwards, T., Schnyder, G., \& Fortwengel, J. (2019). Mapping the impact of home- and host-country institutions on human resource management in emerging market multinational companies: A conceptual framework. Thunderbird International Business Review, 61(3), 531-544.

Errunza, V. R., \& Senbet, L. W. (1984). International corporate diversification, market valuation, and size-adjusted evidence. The Journal of Finance, 39(3), 727-743. 
Estrin, S., Ionascu, D., \& Meyer, K. (2007). Formal and informal institutional distance, and international entry strategies. Social Science Research Network William Davidson Institute Working Paper No. 728. Available at SSRN: http://ssrn.com/abstract=665110. Accessed 25 Oct 2019.

Evergreen Marine Corp (2019). 2018 Annual Report. https://www.evergreen-marine.com/tbf1/jsp/ TBF1_FinancialReports.jsp. Accessed 25 Oct 2019.

Far Eastern Group. (2019). Far Eastern Group-About FEG. http://www.feg.com.tw/en/about/overview. aspx. Accessed 12 May 2019.

Farh, J.-L., Tsui, A. S., Xin, K., \& Cheng, B.-S. (1998). The influence of relational demography and guanxi: The Chinese case. Organization Science, 9(4), 471-488.

Fortwengel, J. (2017). Understanding when MNCs can overcome institutional distance: A research agenda. Management International Review, 57(6), 793-814.

Gaur, A. S., \& Delios, A. (2015). International diversification of emerging market firms: The role of ownership structure and group affiliation. Management International Review, 55(2), 235-253.

Gaur, A. S., Delios, A., \& Singh, K. (2007). Institutional environments, staffing strategies, and subsidiary performance. Journal of Management, 33(4), 611-636.

Gaur, A. S., \& Kumar, V. (2009). International diversification, business group affiliation and firm performance: Empirical evidence from India. British Journal of Management, 20(2), 172-186.

Gaur, A. S., \& Lu, J. W. (2007). Ownership strategies and survival of foreign subsidiaries: Impacts of institutional distance and experience. Journal of Management, 33(1), 84-110.

Gaur, A. S., Pattnaik, C., Singh, D., \& Lee, J. Y. (2019). Internalization advantage and subsidiary performance: The role of business group affiliation and host country characteristics. Journal of International Business Studies, 50(8), 1253-1282.

Gedajlovic, E., \& Carney, M. (2010). Markets, hierarchies, and families: Toward a transaction cost theory of the family firm. Entrepreneurship Theory and Practice, 34(6), 1145-1172.

Ghoshal, S., \& Bartlett, C. A. (1990). The multinational corporation as an inter-organizational network. Academy of Management Review, 15(4), 603-625.

Gómez-Mejía, L. R., Cruz, C., Berrone, P., \& De Castro, J. (2011). The bind that ties: Socioemotional wealth preservation in family firms. Academy of Management Annals, 5(1), 653-707.

Gómez-Mejía, L. R., Haynes, K. T., Núñez-Nickel, M., Jacobson, K. J., \& Moyano-Fuentes, J. (2007). Socioemotional wealth and business risks in family-controlled firms: Evidence from Spanish olive oil mills. Administrative Science Quarterly, 52(1), 106-137.

Gómez-Mejía, L. R., Núñez-Nickel, M., \& Gutierrez, I. (2001). The role of family ties in agency contracts. Academy of Management Journal, 44(1), 81-95.

Granovetter, M. (1995). Coase revisited: Business groups in the modern economy. Industrial and Corporate Change, 4(1), 93-130.

Guillén, M. F. (2000). Business groups in emerging economies: A resource-based view. The Academy of Management Journal, 43(3), 362-380.

Habbershon, T. G., \& Williams, M. L. (1999). A resource-based framework for assessing the strategic advantages of family firms. Family Business Review, 12(1), 1-25.

Hennart, J.-F., Majocchi, A., \& Forlani, E. (2017). The myth of the stay-at-home family firm: How family-managed SMEs can overcome their internationalization limitations. Journal of International Business Studies, 50(5), 758-782.

Hernandez, E., \& Guillén, M. F. (2018). What's theoretically novel about emerging-market multinationals? Journal of International Business Studies, 49(1), 24-33.

Hernández, V., Nieto, M. J., \& Boellis, A. (2018). The asymmetric effect of institutional distance on international location: Family versus nonfamily firms. Global Strategy Journal, 8(1), 22-45.

Hitt, M. A., Hoskisson, R. E., \& Kim, H. (1997). International diversification: Effects on innovation and firm performance in product diversified firms. Academy of Management Journal, 40(4), 767-798.

Hofstede, G. (1980). Culture's consequences: International differences in work-related values, Crosscultural research and methodology series 5. Beverly Hills: Sage.

Hsueh, J. W. J., \& Gomez-Solorzano, M. (2019). Social tie heterogeneity and firms' networking strategy. Entrepreneurship Theory and Practice, 43(2), 352-359.

IMD. (1999). World Competitiveness Yearbook. Lausanne: IMD.

IMD. (2000). World Competitiveness Yearbook. Lausanne: IMD.

IMD. (2001). World Competitiveness Yearbook. Lausanne: IMD.

IMD. (2002). World Competitiveness Yearbook. Lausanne: IMD.

IMD. (2003). World Competitiveness Yearbook. Lausanne: IMD. 
Jackson, G., \& Apostolakou, A. (2010). Corporate social responsibility in Western Europe: an institutional mirror or substitute? Journal of Business Ethics, 94(3), 371-394.

Jaskiewicz, P., Combs, J. G., Shanine, K. K., \& Kacmar, K. M. (2017). Introducing the family: A review of family science with implications for management research. Academy of Management Annals, 11(1), 309-341.

Jepperson, R. L. (1991). Institutions, institutional effects, and institutionalism. In W. W. Powell \& P. J. DiMaggio (Eds.), The new institutionalism in organizational analysis (pp. 143-163). Chicago: University of Chicago Press.

Johanson, J., \& Vahlne, J.-E. (1977). The Internationalization process of the firm-A model of knowledge development and increasing foreign market commitments. Journal of International Business Studies, 8(1), 23-32.

Johanson, J., \& Vahlne, J.-E. (2009). The Uppsala internationalization process model revisited: From liability of foreignness to liability of outsidership. Journal of International Business Studies, 40(9), 1411-1431.

Khanna, T., \& Palepu, K. (2000). The future of business groups in emerging markets: Long-run evidence from Chile. Academy of Management journal, 43(3), 268-285.

Khanna, T., \& Rivkin, J. W. (2001). Estimating the performance effects of business groups in emerging markets. Strategic Management Journal, 22(1), 45-74.

Khanna, T., \& Rivkin, J. W. (2006). Interorganizational ties and business group boundaries: Evidence from an emerging economy. Organization Science, 17(3), 333-352.

Khanna, T., \& Yafeh, Y. (2007). Business groups in emerging markets: Paragons or parasites? Journal of Economic literature, 45(2), 331-372.

Kilduff, M., \& Tsai, W. (2003). Social networks and organizations. Thousand Oaks: Sage.

Kostova, T. (1999). Transnational transfer of strategic organizational practices: A contextual perspective. Academy of Management Review, 24(2), 308-324.

Kostova, T., \& Roth, K. (2002). Adoption of an organizational practice by subsidiaries of multinational corporations: Institutional and relational Effects. Academy of Management Journal, 45(1), 215-233.

Kostova, T., \& Zaheer, S. (1999). Organizational legitimacy under conditions of complexity: The case of the multinational enterprise. Academy of Management Review, 24(1), 64-81.

Kotlar, J., \& Sieger, P. (2019). Bounded rationality and bounded reliability: A study of non-family managers' entrepreneurial behavior in family firms. Entrepreneurship Theory and Practice, 43(2), 251-273.

La Porta, R., Lopez-De-Silanes, F., \& Shleifer, A. (1999). Corporate ownership around the world. The Journal of Finance, 54(2), 471-517.

Lasserre, P., \& Schütte, H. (2006). Strategies for Asia Pacific: Meeting new challenges (3rd ed.). London: MacMillan Press Ltd.

Leff, N. H. (1978). Industrial organization and entrepreneurship in the developing countries: The economic groups. Economic Development and Cultural Change, 26(4), 661-675.

Leitch, C. M., McMullan, C., \& Harrison, R. T. (2013). The development of entrepreneurial leadership: The role of human, social and institutional capital. British Journal of Management, 24(3), $347-366$.

Luo, X. R., \& Chung, C.-N. (2005). Keeping it all in the family: The role of particularistic relationships in business group performance during institutional transition. Administrative Science Quarterly, 50(3), 404-439.

Luo, X. R., \& Chung, C.-N. (2013). Filling or abusing the institutional void? Ownership and management control of public family businesses in an emerging market. Organization Science, 24(2), 591-613.

Luo, Y. (2000). Dynamic capabilities in international expansion. Journal of World Business, 35(4), 355-378.

Manev, I. M. (2003). The managerial network in a multinational enterprise and the resource profiles of subsidiaries. Journal of International Management, 9(2), 133-151.

Manev, I. M., \& Stevenson, W. B. (2001). Nationality, cultural distance, and expatriate status: Effects on the managerial network in a multinational enterprise. Journal of International Business Studies, 32(2), 285-302.

Meyer, J. W., \& Rowan, B. (1977). Institutionalized organizations: Formal structure as myth and ceremony. American Journal of Sociology, 83(2), 340-363.

Miller, D., \& Le Breton-Miller, I. (2006). Family governance and firm performance: Agency, stewardship, and capabilities. Family Business Review, 19(1), 73-87. 
Miller, D., Le Breton-Miller, I., Amore, M. D., Minichilli, A., \& Corbetta, G. (2017). Institutional logics, family firm governance and performance. Journal of Business Venturing, 32(6), 674-693.

Morck, R., Wolfenzon, D., \& Yeung, B. (2005). Corporate governance, economic entrenchment, and growth. Journal of Economic Literature, 43(3), 655-720.

Mukherjee, K., Rautiainen, M., Pihkala, T., \& Rosa, P. (2019). The Dynamics and Complexity of Family Business Groups. In The Family Business Group Phenomenon (pp. 177-200). Cham: Palgrave Macmillan.

North, D. C. (1990). Institutions, institutional change and economic performance. New York: Cambridge University Press.

Peng, M. W. (2003). Institutional transitions and strategic choices. Academy of Management Review, 28(2), 275-296.

Peng, M. W., \& Heath, P. S. (1996). The growth of the firm in planned economies in transition: Institutions, organizations, and strategic choice. Academy of Management Review, 21(2), 492-528.

Peng, M. W., \& Jiang, Y. (2010). Institutions behind family ownership and control in large firms. Journal of Management Studies, 47(2), 253-273.

Peng, M. W., Sun, W., Vlas, C., Minichilli, A., \& Corbetta, G. (2018). An institution-based view of large family firms: A recap and overview. Entrepreneurship Theory and Practice, 42(2), 187-205.

Peng, Z., Qin, C., Chen, R. R., Cannice, M. V., \& Yang, X. (2017). Towards a framework of reverse knowledge transfer by emerging economy multinationals: Evidence from Chinese MNE subsidiaries in the United States. Thunderbird International Business Review, 59(3), 349-366.

Penrose, E. T. (1959). The theory of the growth of the firm. Oxford: Basil Blackwell.

Peterson, M. F., Arregle, J.-L., \& Martin, X. (2012). Multilevel models in international business research. Journal of International Business Studies, 43(5), 451-457.

Phillips, N., \& Tracey, P. (2009). Institutional theory and the MNC. Academy of Management Review, 34(1), 169-171.

Phillips, N., Tracey, P., \& Karra, N. (2009). Rethinking institutional distance: Strengthening the tie between new institutional theory and international management. Strategic Organization, 7(3), 339-348.

Piana, B. D., Vecchi, A., \& Jimenez, A. (2018). Embracing a new perspective on the governance of family business groups: A cross-cultural perspective. European Journal of International Management, 12(3), 223-254.

Pihkala, T., Goel, S., Rautiainen, M., Mukherjee, K., \& Ikävalko, M. (2019). Deciphering ownership of family business groups. In The Family Business Group Phenomenon (pp. 223-252). Cham: Palgrave Macmillan.

Platje, J. (2008). An institutional capital approach to sustainable development. Management of Environmental Quality: An International Journal, 19(2), 222-233.

Prahalad, C. K., \& Doz, Y. L. (1987). The multinational mission: Balancing local demands and global vision. New York: Free Press.

Purkayastha, S., Kumar, V., \& Lu, J. W. (2017). Business group heterogeneity and the internationalization-performance relationship: Evidence from Indian business groups. Asia Pacific Journal of Management, 34(2), 247-279.

Rabe-Hesketh, S., \& Skrondal, S. A. (2012). Multilevel and longitudinal modeling using Stata (3rd ed.). College Station: Stata Press Publication.

Rosa, P., Rautiainen, M., \& Pihkala, T. (2019). The methodological challenges of researching familyowned business groups. In The family business group phenomenon (pp. 37-62). Cham: Palgrave Macmillan.

Rugman, A. M., \& Verbeke, A. (2004). A perspective on regional and global strategies of multinational enterprises. Journal of International Business Studies, 35(1), 3-18.

Rugman, A. M., \& Verbeke, A. (2005). Towards a theory of regional multinationals: A transaction cost economics approach. Management International Review, 45(1), 5-17.

Rugman, A. M., \& Verbeke, A. (2008). A new perspective on the regional and global strategies of multinational services firms. Management International Review, 48(4), 397-411.

Rugman, A. M., Verbeke, A., \& Nguyen, Q. T. (2011). Fifty years of international business theory and beyond. Management International Review, 51(6), 755-786.

Sauerwald, S., \& Peng, M. W. (2013). Informal institutions, shareholder coalitions, and principalprincipal conflicts. Asia Pacific Journal of Management, 30(3), 853-870. 
Schaaper, J., Amann, B., Jaussaud, J., Nakamura, H., \& Mizoguchi, S. (2013). Human resource management in Asian subsidiaries: Comparison of French and Japanese MNCs. The International Journal of Human Resource Management, 24(7), 1454-1470.

Scott, W. R. (1995). Institutions and organizations. Thousand Oaks: Sage.

Sirmon, D. G., \& Hitt, M. A. (2003). Managing resources: Linking unique resources, management, and wealth creation in family firms. Entrepreneurship Theory and Practice, 27(4), 339-358.

Steier, L. P. (2003). Variants of agency contracts in family-financed ventures as a continuum of familial altruistic and market rationalities. Journal of Business Venturing, 18(5), 597-618.

Steier, L. P. (2009). Familial capitalism in global institutional contexts: Implications for corporate governance and entrepreneurship in East Asia. Asia Pacific Journal of Management, 26(3), 513.

Tabor, W., Chrisman, J. J., Madison, K., \& Vardaman, J. M. (2018). Nonfamily members in family firms: A review and future research agenda. Family Business Review, 31(1), 54-79.

Tan, D., \& Mahoney, J. T. (2003). Explaining the utilization of managerial expatriates from the perspectives of resource-based, agency, and transaction-cost theories. In J. Cheng \& M. Hitt (Eds.), Managing multinationals in a knowledge economy: Economics, culture, advances in international management (pp. 179-205). Bradford: Emerald Group Publishing Limited.

Trevino, L. J., \& Grosse, R. (2002). An analysis of firm-specific resources and foreign direct investment in the United States. International Business Review, 11(4), 431-452.

Tsui, A. S., \& O'Reilly, C. A. (1989). Beyond simple demographic effects: The importance of relational demography in superior-subordinate dyads. Academy of Management Journal, 32(2), 402-423.

Vahlne, J.-E., \& Johanson, J. (2017). From internationalization to evolution: The Uppsala model at 40 years. Journal of International Business Studies, 48(9), 1087-1102.

Vandekerkhof, P., Steijvers, T., Hendriks, W., \& Voordeckers, W. (2015). The effect of organizational characteristics on the appointment of nonfamily managers in private family firms: The moderating role of socioemotional wealth. Family Business Review, 28(2), 104-122.

Verbeke, A., \& Kano, L. (2012). The transaction cost economics theory of the family firm: Family-based human asset specificity and the bifurcation bias. Entrepreneurship Theory and Practice, 36(6), 1183-1205.

Verbeke, A., \& Kano, L. (2016). An internalization theory perspective on the global and regional strategies of multinational enterprises. Journal of World Business, 51(1), 83-92.

Wan, W. P., \& Hoskisson, R. E. (2003). Home country environments, corporate diversification strategies, and firm performance. Academy of Management journal, 46(1), 27-45.

Xu, D., Pan, Y., \& Beamish, P. W. (2004). The effect of regulative and normative distances on MNE ownership and expatriate strategies. Management International Review, 44(3), 285-307.

$\mathrm{Xu}, \mathrm{D} .$, \& Shenkar, O. (2002). Institutional distance and the multinational enterprise. Academy of Management Review, 27(4), 608-618.

Yiu, D., Lu, Y., Bruton, G. D., \& Hoskisson, R. E. (2007). Business groups: An integrated model to focus future research. Journal of Management Studies, 44(8), 1551-1579.

Yiu, D., \& Makino, S. (2002). The choice between joint venture and wholly owned subsidiary: An institutional perspective. Organization Science, 13(6), 667-683.

Young, M. N., Peng, M. W., Ahlstrom, D., Bruton, G. D., \& Jiang, Y. (2008). Corporate governance in emerging economies: A review for the principal- principal perspective. Journal of Management Studies, 45(1), 196-220.

Young, M. N., Tsai, T., Wang, X., Liu, S., \& Ahlstrom, D. (2014). Strategy in emerging economies and the theory of the firm. Asia Pacific Journal of Management, 31(2), 331-354.

Zaheer, S. (1995). Overcoming the liability of foreignness. Academy of Management Journal, 38(2), $341-363$.

Zahra, S. (2003). International expansion of U.S. manufacturing family businesses: The effect of ownership and involvement. Journal of Business Venturing, 18(4), 495-512.

Zellweger, T. M. (2017). Managing the family business: Theory and practice. Cheltenham: Edward Elgar.

Zellweger, T. M., Chrisman, J. J., Chua, J. H., \& Steier, L. P. (2019). Social structures, social relationships, and family firms. Entrepreneurship Theory and Practice, 43(2), 207-223.

Publisher's Note Springer Nature remains neutral with regard to jurisdictional claims in published maps and institutional affiliations. 